\title{
TRANSCRANIAL DIRECT-CURRENT STIMULATION IN COMBINATION WITH EXERCISE: A SYSTEMATIC REVIEW
}

\author{
ESTIMULAÇÃO TRANSCRANIANA POR CORRENTE CONTÍNUA EM COMBINAÇÃO COM O EXERCÍCIO: \\ UMAREVISÃOSISTEMÁTICA
}

ReView Article

ARTIGO DE REVISÃo ARtículo de REVISIÓN

ESTIMULACIÓN TRANSCRANEANA POR CORRIENTE CONTINUA EN COMBINACIÓN CON EL EJERCICIO: UNA REVISIÓN SISTEMÁTICA

Leonardo Vinicius Diniz Cavalcante da Silva $a^{1,2}$

(Physical Education Professional)

Flávia Porto ${ }^{3}$

(Physical Education Professional)

Felipe Fregni ${ }^{4}$

(Physician)

Jonas Lírio Gurgel 2,5

(Physical Education Professional)

1. Centro Municipal de Saúde Fernando Antônio Braga Lopes, Rio de Janeiro, RJ, Brazil.

2. Universidade Federal Fluminense, Academic Healthcare Science Program, School of Nursing, Niterói, RJ, Brazil.

3. Universidade do Estado do Rio de Janeiro, Instituto de Educação Física e Desportos, Graduate Program in Sport and Exercise Sciences, Rio de Janeiro, RJ, Brazil.

4. Spaulding Neuromodulation

Center, Spaulding Rehabilitation

Hospital and Massachusetts

General Hospital, Harvard Medical

School, Massachusetts, Boston,

United States of America.

5. Universidade Federal Fluminense, Instituto de Educação Física, Niterói, RJ, Brazil.

Correspondence:

Jonas Lírio Gurgel. Universidade Federal Fluminense. Instituto de Educação Física. Av. Visconde do Rio Branco, s/n. Centro, Niterói, RJ, Brazil. 24020-000.

jonasgurgel@terra.com.br

\begin{abstract}
Introduction: Transcranial direct-current stimulation (tDCS) is a noninvasive technique that allows the modulation of cortical excitability and can produce changes in neuronal plasticity. The application of tDCS has recently been associated with physical activity. Objectives: To verify the effect of Transcranial Direct-Current Stimulation (tDCS) in combination with physical exercise, characterizing methodological aspects of the technique. Methods: In the database search, studies with animals, other neuromodulation techniques and opinion and review articles were excluded. Publications up to 2016 were selected and the methodological quality of the articles was verified through the PEDro scale. Results: The majority of studies (86\%) used tDCS on the motor cortex area, with anodal current and the allocation of monocephalic electrodes (46.5\%). The prevalent current intensity was $2 \mathrm{~mA}(72 \%)$, with duration of $20 \mathrm{~min}(55.8 \%)$. The profile of the research participants was predominantly of subjects aged up to 60 years (72.1\%). The outcomes were favorable for the use of anodal tDCS in combination with physical exercise. Conclusion: Transcranial Direct-Current Stimulation is a promising technique when used in combination with aerobic and anaerobic exercises; however, it is necessary to investigate concurrent exercise. Level of Evidence II; Therapeutic Studies Investigating the Results of Treatment (systematic review of Level II studies or Level I studies with inconsistent results).
\end{abstract}

Keywords: Electrical stimulation; Transcranial direct current stimulation; Physical activity.

\section{RESUMO}

Introdução: A estimulação transcraniana por corrente contínua (ETCC) é uma técnica não invasiva que permite a modulação da excitabilidade cortical e pode produzir alterações na plasticidade neuronal. A aplicação da ETCC tem sido recentemente associada à atividade física. Objetivos: Verificar o efeito da Estimulação Transcraniana por Corrente Contínua (ETCC) em combinação com o exercício físico, caracterizando os aspectos metodológicos da técnica. Métodos: Na busca em base de dados, excluíram-se estudos com animais e outras técnicas de neuromodulação, além de artigos de revisão e opinião. Foram selecionadas publicações a té 2016 e a qualidade metodológica dos artigos foi verificada através da escala PEDRo. Resultados: A maioria dos estudos (86\%) utilizou a ETCC na área do córtex motor, com corrente anódica e montagem monocefálica (unipolar) (46,5\%). A intensidade da corrente dominante foi $2 \mathrm{~mA}$ (72\%) com duração de $20 \mathrm{~min}(55,8 \%)$. O perfil dos participantes da pesquisa foi predominantemente de indivíduos com até 60 anos de idade (72,1\%). Os desfechos foram favoráveis ao uso da ETCC anódica em combinação com o exercício físico. Conclusão: A Estimulação Transcraniana por Corrente Contínua é uma técnica promissora quando utilizada em combinação com os os exercícios aeróbicos e anaeróbicos; entretanto, énecessário investigar o exercício concomitante. Nível de evidência ll; Estudos terapêuticos investigando os resultados do tratamento (revisão sistemática dos estudos de nível Il ou estudos de nível I com resultados inconsistentes).

Descritores: Estimulação Elétrica; Estimulação transcraniana por corrente contínua; Exercício físico.

\section{RESUMEN}

Introducción: La estimulación transcraneana por corriente continua (ETCC) es una técnica no invasiva que permite la modulación de la excitabilidad cortical y puede producir alteraciones en la plasticidad neuronal. La aplicación de la ETCC ha sido recientemente asociada a la actividad física. Objetivos: Verificar el efecto de la Estimulación Transcraneana por Corriente Continua (ETCC) en combinación con el ejercicio físico, caracterizando los aspectos metodológicos de la técnica. Métodos: En la búsqueda en base de datos, se excluyeron estudios con animales y otras técnicas de neuromodulación, además de artículos de revisión y opinión. Fueron seleccionadas publicaciones hasta 2016 y la calidad metodológica de los artículos fue verificada a través de la escala PEDRo. Resultados: La mayoría de los estudios (86\%) utilizó la ETCC en el área del córtex motor, con corriente anódica y montaje monocefálico (unipolar) (46,5\%). La intensidad de la corriente dominante fue $2 \mathrm{~mA}$ (72\%) con duración de 20 min (55,8\%). El perfil de los participantes de la investigación fue predominantemente de individuos con hasta 60 años de edad (72,1\%). Los desenlaces fueron favorables al uso de la ETCC anódica en combinación con el ejercicio físico. Conclusión: La Estimulación Transcraneana 
por Corriente Continua es una técnica alentadora cuando utilizada en combinación con los ejercicios aeróbicos y anaeróbicos; entretanto, es necesario investigar el ejercicio concomitante. Nivel de evidencia Il; Estudios terapéuticos investigando los resultados del tratamiento (revisión sistemática de los estudios de nivel Il o estudios de nivel I con resultados inconsistentes).

Descriptores: Estimulación eléctrica; Estimulación transcraneal de corriente directa; Ejercicio físico.

\section{INTRODUCTION}

Transcranial direct-current stimulation (tDCS) is a noninvasive technique that allows the modulation of cortical excitability and can produce changes in neuronal plasticity. Through an electric current with a low amperage, positive (anodal) polarity increases cortical excitability and negative (cathodal) decreases it. ${ }^{1,2}$ Basically, the application of tDCS is performed using two silicone electrodes, $5 \mathrm{~cm} \times 7 \mathrm{~cm}$ in size, surrounded by a sponge soaked in saline solution and a device that provides low amperage current (0.4-2.0mA) continuously (3-20min). ${ }^{3}$

Regarding electrode positioning, one possibility is the bi-cephalic montage, in which an anodal ${ }^{4}$ or cathodal current electrode 4 is positioned over a cerebral region (for example, over the area of the motor cortex) and the other, called the'reference', is positioned over another cerebral region (example, over the prefrontal cortex). In the uni-cephalic montage, an electrode with anodal or cathodal current stimulates a certain brain region, while the other electrode is placed over an extracephalic region. ${ }^{5}$ In the bi-hemispherical technique, ${ }^{6}$ the two electrodes stimulate the same brain region, however, in antagonistic positions, that is, one electrode can be located on the left temporal cortex and another on the right temporal cortex.

To define the brain region to be stimulated is also something that lacks agreement in the scientific literature. This is because there are several brain areas that can exert control over a particular physiological or motor reaction as a result of physical exercise. It is hypothesized, then, that the excitatory or inhibitory action of the tDCS may be in part related to the brain region stimulated and the type of physical exercise proposed. . $^{-10}$ The intensity of the current also seems to influence the study results, with intensities of $1.0 \mathrm{~mA},{ }^{11} 1.5 \mathrm{~mA}^{12}$ and $2.0 \mathrm{~mA}^{13}$ possibly presenting different results. The time of exposure to the stimulation has also not been standardized, and may vary from 10 to 40 min. ${ }^{14,15}$

Exercise, in turn, when associated with tDCS, may present optimized performance with improved oxygen consumption, ${ }^{16}$ in the case of aerobic exercises, and increased strength, ${ }^{17}$ in the case of resistance exercises. Finally, the profile of individuals submitted to tDCS, such as young people and older adults, seems to influence the results: due to the anatofunctional alterations of the older adult brain, ${ }^{18}$ allowing greater conduction when compared to a younger individuals.

This systematic review aimed to map the methodological aspects of tDCS associated with exercise. The following were considered as the variables of analysis, the type, time and intensity of the current tested, location of the cortex for current application, type of electrode montage, profile of individuals studied, type of physical exercise associated with the use of tDCS and the methodological design of the study.

\section{METHOD}

Initially, this review was registered on the PROSPERO database (International Prospective Register of Systematic Reviews), ${ }_{1}^{19}$ under ID number $=$ CRD42017060270, with the PRISMA recommendations followed. ${ }^{20}$

\section{Search for material}

The search for articles occurred in the MEDLINE, CAPES periodicals, Cochrane and SciELO databases. For the selection of key terms, the Medical Subject Headings (MeSH) list was consulted. The terms used to search, in Portuguese and English, were: Electric Cerebral Stimulation, Aerobic Exercise, tDCS, Transcranial direct-current stimulation, Exercise, Concurrent Training, Anaerobic Exercise. These terms were combined with the Boolean connectors OR between the synonyms and to establish the relationship between tDCS and exercise.

\section{Inclusion criteria for the articles}

The articles were included in the study when they presented, as an independent variable, tDCS associated with physical exercise, which could be aerobic, anaerobic or concurrent. As a dependent variable, physiological and/or biomechanical changes were considered as the effect of the physical exercise. Studies with animals and neuromodulation techniques other than tDCS and opinion and review articles were excluded.

\section{Eligibility criteria}

Articles in Portuguese or English published up to 9/22/2016. In order to select the articles of the search, the titles and abstracts were read, with the aim of analyzing whether the article met the inclusion and exclusion criteria, using the Skimming reading technique.21 If, however, doubts remained about the need to include the article in this study, a full reading of the studies found was performed. In the process of searching for articles, there was no type of delimitation for the population studied. Also, all forms of tDCS application, types of physical training, duration of electrostimulation, current intensity and brain regions stimulated were accepted.

\section{Analysis of the articles}

The articles were submitted to a descriptive analysis, carried out by two researchers who evaluated the methodological quality of the articles through the PEDro scale. ${ }^{22}$ Figure 1 shows the selection process of the articles.

The studies were summarized through descriptive statistics, with absolute and relative frequency of the items: study design, gender of the individuals investigated, mean age of the volunteers, tDCS techniques, brain areas stimulated, current intensity and duration of stimulation.

\section{RESULTS}

A total of 43 articles that met the inclusion criteria were retrieved. The first article was published in 2007 and the majority of the articles were published between 2013 and 2016.

\section{Design of the studies}

The majority of the studies were experimental (97.7\%), with a crossover design being the most used (61\%), followed by a parallel design (37\%), and one case report design (2\%). Most of the experimental studies were double-blind (60\%); with the tDCS being the blind experimental part in all the studies.

\section{Area of stimulation, intensity, duration of the current}

The majority of the studies aimed to use exercise as a potentiator of the tDCS in the motor cortex, thus, $86 \%$ of the studies used this area as a stimulation area; with the anodal current being the most used for this. 




Figure 1. Stages of selection of the articles.

Regarding the intensity of the current, the majority of the studies applied $2 \mathrm{~mA}(72 \%)$. The duration of the tDCS application was 20 minutes (55.8\%) and 15 minutes (25.7\%). Table 1 shows the methodological characterization of tDCS used in the studies analyzed.

Table 2 presents information related to authors, methodological classification through the PEDro scale, methods, year of publication, protocol and the main results of the studies analyzed.

\section{DISCUSSION}

This systematic review showed that there are a relatively high number of clinical studies on this topic (43 articles with a total of 909 subjects tested). Although the clinical methodology of the studies tested was evaluated with the PEDRo scale, these studies are still few and have heterogeneity in the outcomes and population studied. There were also few mechanistic studies.

As shown in Table 1, all the studies presented the clinical study method and were randomized, and of these, 7 presented more robust methods in the description of what was performed in the study. The fact that these studies were carried out in a double-blind manner minimized possible bias. However, a large number of studies were not performed in a randomized double-blind manner, which may have led to biases in the quantification of the results. This assumption is based on the need for double-blind randomized methodological control, as this is able to minimize biases with greater efficiency. ${ }^{41}$ However, blinding is not always possible, as sometimes studies present techniques that are not automated, which makes the study blinding difficult. Thus, in these cases, the orientation for researchers is to minimize the possible influences of other techniques or treatments that may impact on the results ${ }^{41}$ or to use more objective clinical outcomes. ${ }^{49-51}$

There are other methodological issues that need to be carefully observed regarding the use of tDCS and stimulation parameters. The first is related to the type of stimulation the individuals are to be submitted to, such as anodal, cathodal or bicephalic montage. ${ }^{43}$ Some studies used parameters that have been studied little, such as temporal cortex stimulation. Montenegro et al. ${ }^{48}$ when stimulating the temporal cortex of athletes by anodal tDCS, expected to find a greater participation of the parasympathetic activity and a reduction of the sympathetic activity, thus modulating the heart rate. Based on this study, it would be possible to state that, in these situations, anodal tDCS also shows an efficient method to modulate the cardiorespiratory variables during physical exercise.
Table 1. Characterization of the tDCS in the 43 articles analyzed.

\begin{tabular}{|c|c|c|}
\hline & $\begin{array}{l}\text { Absolute } \\
\text { Frequency }\end{array}$ & $\begin{array}{l}\text { Relative } \\
\text { frequency }\end{array}$ \\
\hline \multicolumn{3}{|l|}{ Study design } \\
\hline Randomized crossover & 26 & $60,5 \%$ \\
\hline Randomized parallel & 16 & $37,2 \%$ \\
\hline Case study & 1 & $2,3 \%$ \\
\hline \multicolumn{3}{|l|}{ Blinding of the study } \\
\hline Double-blind (volunteers and evaluators) & 26 & $60,5 \%$ \\
\hline Blind (volunteers) & 17 & $39,5 \%$ \\
\hline \multicolumn{3}{|l|}{ Stimulation techniques } \\
\hline Anodal and cathodal (bi-cephalic) & 3 & $7,0 \%$ \\
\hline Anodal and placebo (uni-cephalic) & 20 & $46,5 \%$ \\
\hline Cathodal and placebo (uni-cephalic) & 2 & $4,7 \%$ \\
\hline Anodal, cathodal or placebo (uni-cephalic) & 7 & $16,3 \%$ \\
\hline $\begin{array}{c}\text { Anodal and cathodal (bi-cephalic) or } \\
\text { Placebo }\end{array}$ & 11 & $25,6 \%$ \\
\hline \multicolumn{3}{|l|}{ Cerebral areas stimulated } \\
\hline Motor córtex & 37 & $86,0 \%$ \\
\hline Prefrontal córtex & 3 & $7,0 \%$ \\
\hline Temporal córtex & 2 & $4,7 \%$ \\
\hline Ipsiolateral córtex & 1 & $2,3 \%$ \\
\hline \multicolumn{3}{|l|}{ Current intensity } \\
\hline $1 \mathrm{~mA}$ & 10 & $23,3 \%$ \\
\hline $1,5 \mathrm{~mA}$ & 2 & $4,7 \%$ \\
\hline $2 \mathrm{~mA}$ & 31 & $72,1 \%$ \\
\hline \multicolumn{3}{|l|}{ Duration of stimulation } \\
\hline 10 minutes & 5 & $11,6 \%$ \\
\hline 13 minutes & 1 & $2,3 \%$ \\
\hline 15 minutes & 11 & $25,6 \%$ \\
\hline 17 minutes & 1 & $2,3 \%$ \\
\hline 20 minutes & 24 & $55,8 \%$ \\
\hline 40 minutes & 1 & $2,3 \%$ \\
\hline \multicolumn{3}{|l|}{ Profile of the sample } \\
\hline \multicolumn{3}{|l|}{ Gender } \\
\hline Men & 14 & $32,6 \%$ \\
\hline Women & 0 & $0,0 \%$ \\
\hline Both & 29 & $67,4 \%$ \\
\hline \multicolumn{3}{|l|}{ Mean of the age group of the volunteers } \\
\hline 60 years or less & 31 & $72,1 \%$ \\
\hline 60 years or more & 7 & $16,3 \%$ \\
\hline Both ages (more and less than 60 years) & 5 & $11,6 \%$ \\
\hline
\end{tabular}

The use of cathodal stimulation had its beneficial effect diagnosed in the improvement of the motor control in people affected by stroke. ${ }^{24}$ In this study, cathodal tDCS was used associated with muscular control of the elbow flexors in post-stroke subjects, classified as having a moderate level of impairment. The study showed that the subjects presented significant results in the increase of the control of the effort of the muscle group related to the brain region injured by the stroke.

In addition to these two forms of stimulation, the third way of stimulating the subjects was through bi-cephalic montage. This stimulation has been performed more in studies with hemiparetic post-stroke subjects. In this situation, the aim is to stimulate, by anodal current, the injured brain region, to excite a region that normally has diminished cortical activity. With the cathodal current, the focus is to decrease the excitability of the region opposite the lesion that may already be excited. ${ }^{22,11,24}$

Regarding the intensity and duration of the stimulations, the studies presented three types of stimulation, with a current of $2 \mathrm{~mA}$ for 40,20 , 15 or 10 minutes, ${ }^{17,12,8,15,4}$ with $1 \mathrm{~mA}$ for 20,15 and 10 minutes $^{16,10,27,7}$ and with $1.5 \mathrm{~mA}$ for 20 minutes. ${ }^{14}$ Despite the discrepancies, Nitsche and Paulus $^{3}$ affirm that, after one hour of tDCS for 20 minutes at $2 \mathrm{~mA}$, it is possible to verify changes in cortical excitability. This may be the reason that the majority of the studies opted for this experimental schema. 
Table 2. Authors, methodological quality, year of publication, study protocol, main results of articles analyzed.

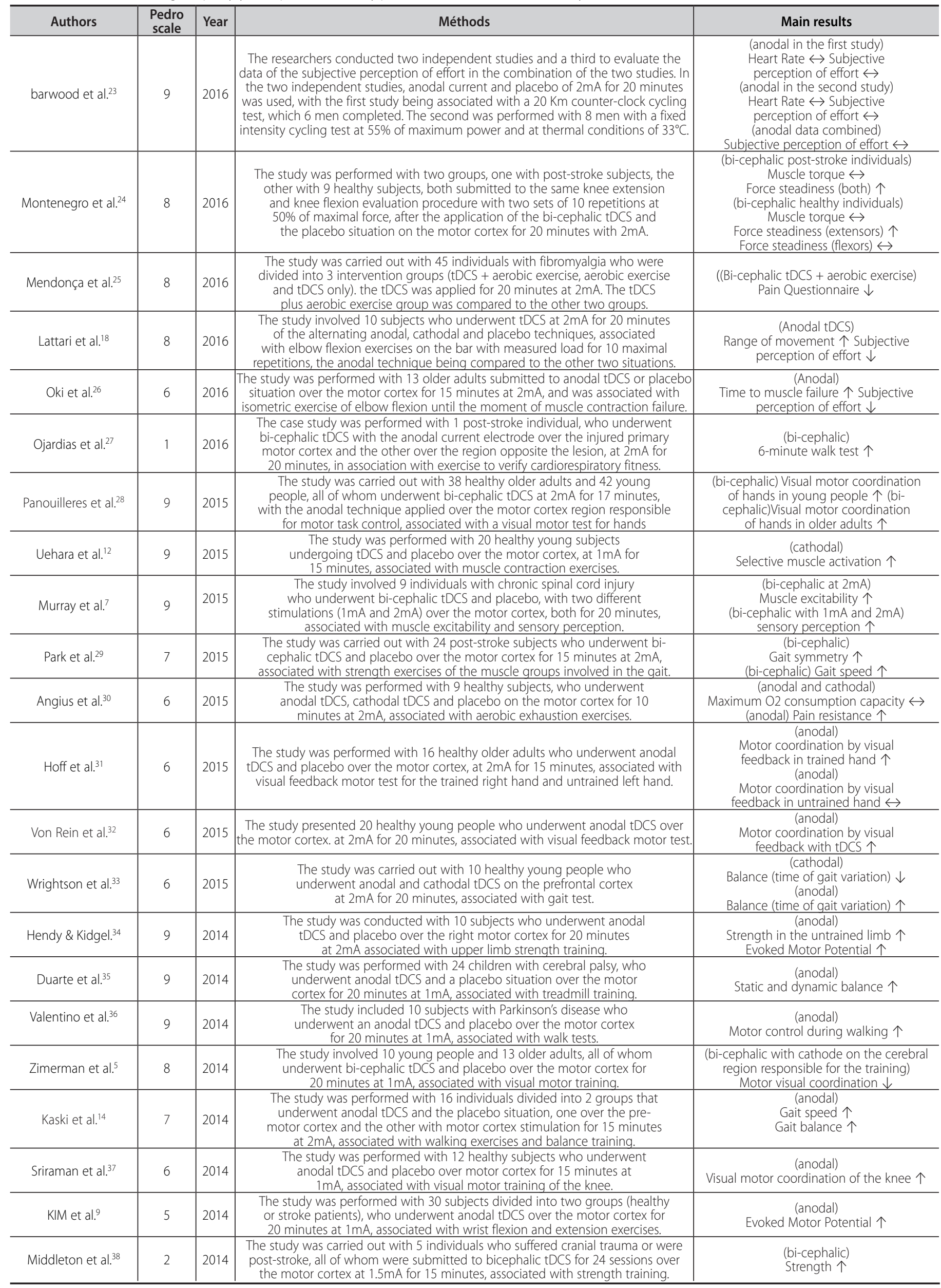


Table 2. Authors, methodological quality, year of publication, study protocol, main results of articles analyzed.

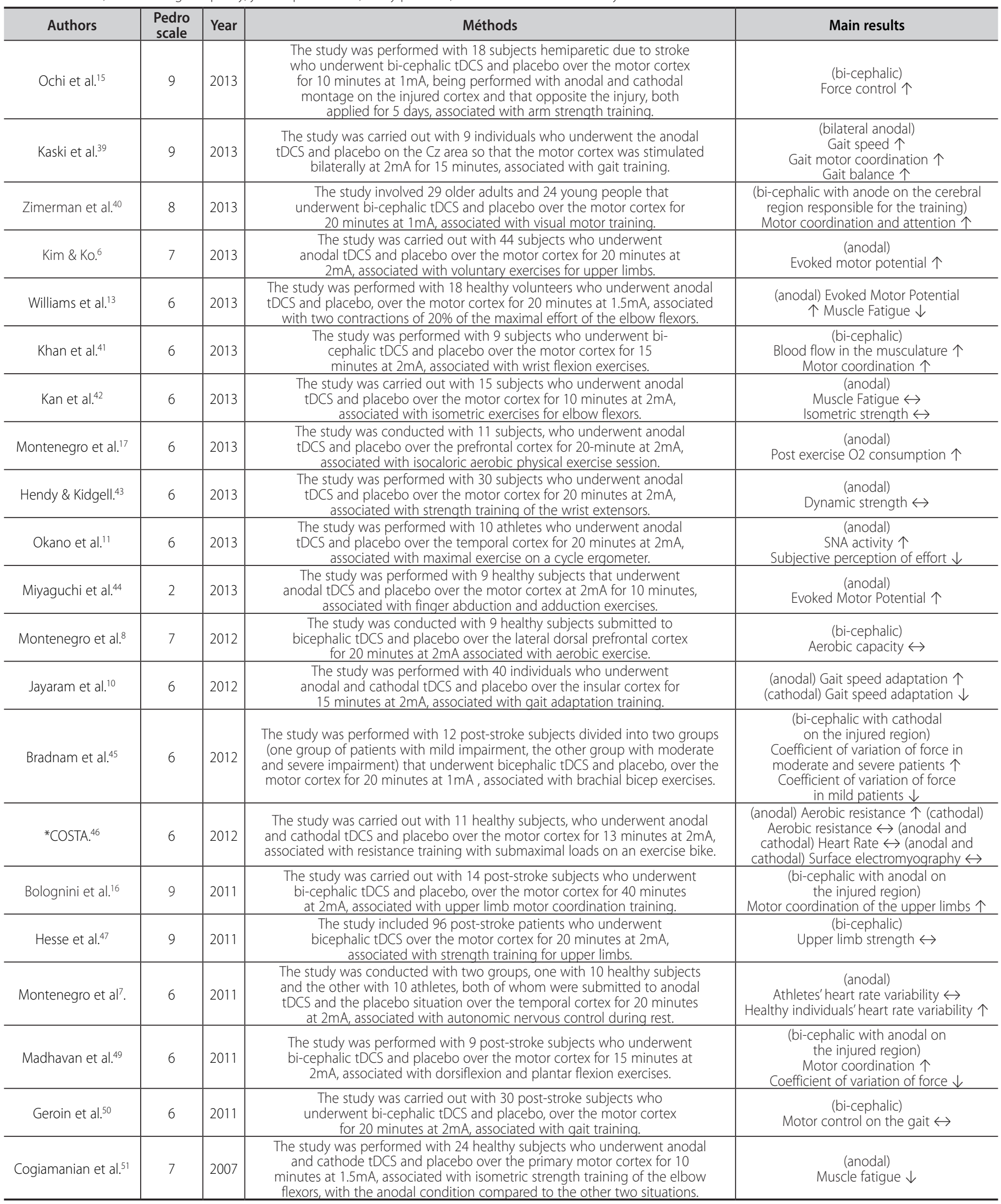

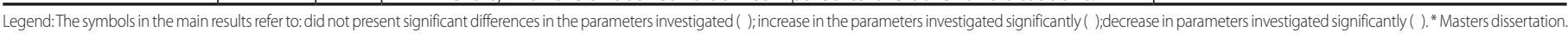

Regarding the area of stimulation, Machado ${ }^{52}$ stated that brain regions are responsible for controlling one or several areas and functions of the body. Therefore, there was difficulty in exactly defining which area to stimulate. These differences in brain controls related to body functions tended to be reflected in the studies of tDCS associated with exercise. The stimulated brain region seen in most of the studies investigating the effect of tDCS on physical activity was the motor cortex, ${ }^{6,18,26}$ The temporal cortex, $^{12,53}$ dorsolateral prefrontal corte ${ }^{54}$ and ipsilateral hemisphere ${ }^{11}$ were other regions studied. A possible explanation for different regions being stimulated in the studies of tDCS associated with physical exercise may be, in the case of subjects with some brain injury, stimulation of the areas corresponding to the location of these lesions. ${ }^{10,24}$ 
The gender of the participants is another point to be discussed, as, of the 43 studies included in the review, only 9 were performed with male-only volunteers, that is, the majority of the studies investigated the effects of tDCS on both genders. Therefore, it is important to emphasize that the participation of individuals of both sexes in the same study should be interpreted carefully, due to the biological differences between the male and female genders, especially in strength patterns. ${ }^{3}$ The studies indicated significant results when men and women underwent tDCS, which may suggest that anyone may be susceptible to the effects of anodal or cathodal stimulation. ${ }^{52,27,8}$

It is also possible to observe that 28 studies were performed with individuals categorized as young adults, thus indicating a possible uniformity in the age group submitted to the tDCS technique. Despite this, five studies ${ }^{10,25,17,7,52}$ showed large differences between the ages of the volunteers and, perhaps, because of this age dispersion, highlighted antagonistic results. Among the five studies with differences in the age range, the one carried out by Zimerman et al. ${ }^{5}$ can be cited, as it presented a population with a large age difference among the participants. In this study young people and older adults underwent cathodal stimulation associated with the motor task, with antagonistic results found. It was possible to verify that only the older adult group presented a significant improvement in the motor behavior.

The study by Bolognini et al, ${ }^{17}$ when distributing stroke patients with different age groups (age 26-75 years) into two groups, found that both groups presented significant changes when submitted to tDCS associated with motor work, that is, regardless of the difference in the age groups, it is possible that tDCS causes significant changes. In the investigation by Madhavan et al. ${ }^{25}$ it is possible to identify that young people and older adults with hemiparesis, when submitted to anodal and cathodal tDCS presented significant changes in the control of lower limb movements. Similarly, healthy and post-stroke individuals who underwent anodal stimulation associated with wrist flexion and extension exercises through videogames and a writing test presented significant changes when compared to similar situations without the use of tDCS. ${ }^{10}$

Although some of the studies discussed in this review are of low intensity physical activity, this does not imply the impoverishment of the tDCS technique when associated with physical exercises of higher intensities. Physical exercises will mostly require a range of less complex motor skills with fewer muscles involved than more complex activities involving a greater variety of musculature worked on in the same session of physical activity. Therefore, it is possible to comprehend, regardless of the muscle group worked on, the importance will be in the physical activity. ${ }^{45,46}$ In addition, Kaski et al. ${ }^{14}$ and Montenegro et al. ${ }^{24}$ presented good perspectives in the association of tDCS and performance of physical valences at higher intensities allowing speculation of a promising future, however, there is a need for further studies regarding these relationships.

\section{CONCLUSION}

Transcranial direct-current stimulation seems to be a promising technique when associated with aerobic and anaerobic exercises, however, more research is needed regarding this association with concurrent physical activity. This is relevant as these two forms of exercise play an important role in physical and mental rehabilitation, disease prevention and maintenance of health, therefore, configure a great opportunity to optimize benefits in health promotion.

\section{ACKNOWLEDGMENT}

Fundação Carlos Chagas Filho de Amparo à Pesquisa do Estado do Rio de Janeiro (FAPERJ). Dr. Felipe Fregni is supported by a NIH grant 1R01AT009491-01A1.

All authors declare no potential conflict of interest related to this article

AUTHORS' CONTRIBUTIONS: Each author made significant individual contributions to this manuscript. LVDC (0000-0003-2076-4019)*: Substantial contribution in the conception or design of the study, or the acquisition, analysis, or interpretation of the study; writing or critical review of the article and its intellectual content; agreeing to take responsibility for all aspects of the study, in the sense of guaranteeing that any issues related to the integrity or precision of any portion of the study were duly studied and resolved. FP (0000-00023811-3188)*: Substantial contribution in the conception or design of the study, or the acquisition, analysis, or interpretation of the study; writing or critical review of the article and its intellectual content; agreeing to take responsibility for all aspects of the study, in the sense of guaranteeing that any issues related to the integrity or precision of any portion of the study were duly studied and resolved. FF (0000-0002-1703-7526)*: Writing or critical review of the article and its intellectual content; agreeing to take responsibility for all aspects of the study, in the sense of guaranteeing that any issues related to the integrity or precision of any portion of the study were duly studied and resolved. JLG (0000-0002-9355-7793)* Substantial contribution in the conception or design of the study, or the acquisition, analysis, or interpretation of the study; final approval of the version of the manuscript to be published. *ORCID (Open Researcher and Contributor ID).

\section{REFERENCES}

1. Fregni F, Boggio PS, Mansur CG, WagnerT, Ferreira MJL, Lima MC, et al. Transcranial direct current stimulation of the una $;$ ected hemisphere in stroke patients. Neuro Rep. 2005;16(14):1551-5.

2. Wagner T, Valero-Cabre A, Pascual-Leone A. Noninvasive human brain stimulation. Annu Rev Biomed Eng. 2007;9:527-65.

3. Nitsche MA, Paulus W. Excitability changes induced in the human motor cortex by weak transcranial direct current stimulation. J Physiol. 2000;527 Pt 3:633-9

4. Vandermeeren Y, Jamart J, Ossemann M. Effect of tDCS with an extracephalic reference electrode on cardio-respiratory and autonomic functions. BMC Neurosci. 2010;11:38.

5. Zimerman M, Heise K, Gerloff C, Cohen LG, Hummel FC. Disrupting the Ipsilateral Motor Cortex Interferes with Training of a Complex Motor Task in Older Adults. Cereb Cortex. 2014;24(April):1030-6.

6. Kim G, Ko M. Facilitation of corticospinal tract excitability by transcranial direct current stimulation combined with voluntary grip exercise. Neurosci Lett. 2013;548:181-4.

7. Murray LM, Edwards DJ, Ruffini G, Labar D, Stampas A, Pascual-leone A, et al. Intensity dependent effects of tDCS on corticospinal excitability in chronic Spinal Cord Injury. Arch Phys Med Rehabil. 2015;96(4 suppl):114-21.

8. Montenegro RA, Okano AH, Cunha FA, Gurgel JL, Fontes EB, Farinatti PTV. Prefrontal cortex transcranial direct current stimulation associated with aerobic exercise change aspects of appetite sensation in overweight adults. Appetite. 2012;58(1):333-8

9. Kim YJ, Ku J, Cho S, Kim HJ, Cho YK, Lim T, et al. Facilitation of corticospinal excitability by virtual reality exercise following anodal transcranial direct current stimulation in healthy volunteers and subacute stroke subjects. J Neuroeng Rehabil. 2014;11(124):1-12.
10. Jayaram G, Tang B, Pallegadda R, Vasudevan EVL, Celnik P, Bastian A. Modulating locomotor adaptation with cerebellar stimulation. J Neurophysiol. 2012;107(February):2950-7.

11. Okano AH, Fontes EB, Montenegro RA, Farinatti PTV, Cyrino ES, Li LM, et al. Brain stimulation modulates the autonomic nervous system , rating of perceived exertion and performance during maximal exercise. Br J Sport Med. 2015;49(18):1213-8.

12. Uehara K, Coxon JP, Byblow WD. Transcranial Direct Current Stimulation Improves Ipsilateral Selective Muscle Activation in a Frequency Dependent Manner. PLoS One. 2015;27(3):1-14.

13. Williams PS, Hoffman RL, Clark BC. Preliminary Evidence That Anodal Transcranial Direct Current Stimulation Enhances Time to Task Failure of a Sustained Submaximal Contraction. PLoS One. 2013;8(12):1-11.

14. Kaski D, Dominguez R, Allum J, Islam A, Bronstein A. Combining physical training with transcranial direct current stimulation to improve gait in Parkinson's disease: a pilot randomized controlled study. Clin Rehabil. 2014;28(11):1115-24.

15. Ochi M, Saeki S, Oda T, Matsushima Y, Hachisuka K. Effects of anodal and cathodal transcranial direct current stimulation combined with robotic therapy on severely affected arms in chronic stroke patients. J Rehabil Med. 2013;45(1):137-40.

16. Bolognini N, Vallar G, Casati C, Latif LA, El-nazer R, Williams J, et al. Neurophysiological and Behavioral Effects of tDCS Combined With Constraint-Induced Movement Therapy in Poststroke Patients. Neurorehabil Neural Repair. 2011;25(9):819-29.

17. Montenegro R, Okano AH, Cunha FA, Fontes EB, Farinatti P. Does Prefrontal Cortex Transcranial Direct Current Stimulation In fl uence the Oxygen Uptake at Rest and Post-exercise? Int J Sports Med. 2014;35(6):459-64

18. Lattari E, Andrade ML, Filho AS, Moura AM, Neto GM, Silva JG, et al. Can Transcranial Direct Current 
Stimulation Improve the Resistance Strength and Decrease the Rating Perceived Scale in Recreational Weight-Training Experience? J strength Cond Res. 2016;30(12):3381-7.

19. PROSPERO [Internet]. 2017 [accessed on 2017 Mar 30] Available at: http://www.crd.york.ac.uk/ PROSPERO/.

20. Moher D, Liberati A, Tetzlaff J, Altman DG. Preferred reporting items for systematic reviews and metaanalyses: the PRISMA statement. Ann Intern Med. 2009;151(4):264-9.

21. Marconi MA, Lakatos EM. Fundamentos de metodologia científica. $2^{\circ}$. Rio de Janeiro: Editora Atlas S.A.; 2003

22. Maher CG, Sherrington C, Herbert RD, Moseley AM, Elkins M. Reliability of the PEDro scale for rating quality of randomized controlled trials. Phys Ther. 2003;83(8):713-21.

23. Barwood MJ, Butterworth J, Goodall S, House JR, Laws R, Nowicky A, et al. The Effects of Direct Current Stimulation on Exercise Performance, Pacing and Perception in Temperate and Hot Environments. Brain Stimul. 2016;9(6):842-9.

24. Montenegro RA, Midgley A, Massaferri R, Bernardes W, Okano AH, Farinatti P. Bihemispheric Motor Cortex Transcranial Direct Current Stimulation Improves Force Steadiness in Post-Stroke Hemiparetic Patients: A Randomized Crossover Controlled Trial. Front Hum Neurosci. 2016;10(August):1-9.

25. Mendonca ME, Simis M, Grecco LC, Battistella LR, Baptista AF, Fregni F. Transcranial Direct Current Stimulation Combined with Aerobic Exercise to Optimize Analgesic Responses in Fibromyalgia: A Randomized Placebo-Controlled Clinical Trial. Front Hum Neurosci. 2016;10(March):1-12.

26. Oki K, Mahato NK, Nakazawa M, Amano S, France CR, Russ DW, et al. Preliminary Evidence Tha Excitatory Transcranial Direct Current Stimulation Extends Time to Task Failure of a Sustained, Submaximal Muscular Contraction in Older Adults. J Gerontol A Biol Sci Med Sci. 2016;71 (8):1109-12.

27. Ojardias É, Azeo O, Rimaud D, Giraux P. Feasibly and tolerance of a rehabilitation program combined with iterative tDCS stimulations for hemiplegic patients after stoke: A case-report study. Ann Phys Rehabil Med. 2016;59(S):78-83.

28. Panouilleres MTN, Joundi RA, Brittain JS, Jenkinson N. Reversing motor adaptation deficits in the ageing brain using non-invasive stimulation. J Physiol. 2015;593(Pt 16):3645-55.

29. Park SD, Kim JY, Song HyS. Effect of application of transcranial direct current stimulation during task-related training on gait ability of patients with stroke. J Phys Ther Sci. 2015;27(3):623-5.

30. Angius L, Hopker JG, Marcora SM, Mauger AR. The effect of transcranial direct current stimulation of the motor cortex on exercise-induced pain. Eur J Appl Physiol. 2015;115(11):2311-9.

31. Hoff M, Kaminski E, Rjosk V, Sehm B, Steele CJ, Villringer A, et al. Augmenting mirror visual feedbackinduced performance improvements in older adults. Eur J Neurosci. 2015;41(11):1475-83.

32. von Rein E, Hoff M, Kaminski E, Sehm B, Steele CJ, Villringer A, et al. Improving motor performance without training: the effect of combining mirror visual feedback with transcranial direct current stimulation. J Neurophysiol. 2015;113(7):2383-9.

33. Wrightson JG, Twomey R, Ross EZ, Smeeton NJ. The effect of transcranial direct current stimulation on task processing and prioritisation during dual-task gait. Exp brain Res. 2015;233(5):1575-83.

34. Hendy AM, Kidgell DJ. Anodal - tDCS applied during unilateral strength training increases strength and corticospinal excitability in the untrained homologous muscle. Exp Brain Res. 2014;232(10):3243-52.

35. Duarte NAC, Grecco LAC, Galli M, Fregni F, Oliveira CS. Effect of transcranial direct-current stimulation combined with treadmill training on balance and functional performance in children with cerebral palsy: a double-blind randomized controlled trial. PLoS One. 2014;9(8):1-8.

36. Valentino F, Cosentino G, Brighina F, Pozzi NG, Sandrini G, Fierro B, et al. Transcranial direct current stimulation for treatment of freezing of gait: a cross-over study. Mov Disord. 2014;29(8):1064-9.
37. Sriraman A, Oishi T, Madhavan S. Timing-dependent priming effects of tDCS on ankle motor skil learning. Brain Res. 2014;1581:23-9.

38. Middleton A, Fritz SL, Liuzzo DM, Newman-Norlund R, HerterTM. Using clinical and robotic assessment tools to examine the feasibility of pairing tDCS with upper extremity physical therapy in patients with stroke and TBI: a consideration-of-concept pilot study. 2014;35(4):741-54.

39. Kaski D, Dominguez RO, Allum JH, Bronstein AM. Improving Gait and Balance in Patients With Leukoaraiosis Using Transcranial Direct Current Stimulation and Physical Training: An Exploratory Study. Neurorehabil Neural Repair. 2013;27(9):864-71.

40. Zimerman M, Nitsch M, Giraux P, Gerloff C, Cohen LG, Hummel FC. Neuroenhancement of the Aging Brain: Restoring Skill Acquisition in Old Subjects. Ann Neurol. 2013;73(1):10-5.

41. Khan B, Hodics T, Hervey N, Kondraske G, Stowe AM, Alexandrakis G. Functional near-infrared spectroscopy maps cortical plasticity underlying altered motor performance induced by transcranial direct current stimulation. J Biomed Opt. 2013;18(11):1-12.

42. Kan B, Dundas JE, Nosaka K. Effect of transcranial direct current stimulation on elbow flexor maxima voluntary isometric strength and endurance. Applied physiology, nutrition, and metabolism. App Physiol Nutr Metab. 2013;38(7):734-9.

43. Hendy AM, Kidgell DJ. Anodal tDCS Applied during Strength Training Enhances Motor Cortical Plasticity. Med Sci Sport Exerc. 2013;45(9):1721-9.

44. Miyaguchi S, Onishi H, Kojima S, Sugawara K, Tsubaki A, Kirimoto H, et al. Corticomotor excitability induced by anodal transcranial direct current stimulation with and without non-exhaustive movement Brain Res. 2013;1529:83-91.

45. Bradnam LV, Stinear CM, Barber PA, Byblow WD. Contralesional Hemisphere Control of the Proximal Paretic Upper Limb following Stroke. Cereb Cortex. 2012;22(November):2662-71.

46. Costa MV. Estimulação Transcraniana Por Corrente Contínua Anódica Aumenta A Tolerância Ao Exercício. Dissertação de Mestrado. Universidade Estadual de Londrina. 2012.

47. Hesse S, Waldner A, Mehrholz J, Tomelleri C, Pohl M, Werner C. Combined transcranial direct curren stimulation and robot-assisted arm training in subacute stroke patients: an exploratory, randomized multicenter trial. Neurorehabil Neural Repair. 2011;25(9):838-46.

48. Montenegro RA, Farinatti P de TV, Fontes EB, Soares PP da S, Cunha FA da, Gurgel JL, et al. Transcrania direct current stimulation influences the cardiac autonomic nervous control. Neuroscience Letters. 2011;497(1):32-6.

49. Madhavan S, Weber KA, Stinear JW. Non-invasive brain stimulation enhances W ne motor control of the hemiparetic ankle : implications for rehabilitation. Exp Brain Res. 2011;209(1):9-17.

50. Geroin C, Picelli A, Munari D, Waldner A, Tomelleri C, Smania N. Combined transcranial direct current stimulation and robot-assisted gait training in patients with chronic stroke : a preliminary comparison. Clin Rehabil. 2011;25(6):537-48.

51. Cogiamanian F, Marceglia S, Ardolino G, Barbieri S, Priori A. Improved isometric force endurance after transcranial direct current stimulation over the human motor cortical areas. Eur J Neurosci. 2007;26(1):242-9

52. Machado A. Estrutura e Funções dos Núcleos da Base e Centro Branco Medular do Cérebro. 20. Neuroanatomia Funcional. 2010. 240-60 p.

53. Cogiamanian F, Brunoni AR, Boggio PS, Fregni F, Ciocca M, Priori A. Non-invasive brain stimulation for the management of arterial hypertension. Med Hypotheses. 2010;74(2):332-6.

54. Hummel FC, Voller B, Celnik P, Floel A, Giraux P, Gerloff C, et al. Effects of Brain polarization on reaction times and pinch force in chronic stroke. BMC Neurosci. 2006;7(73):1-10. 